\title{
Senators warn of changing climate for research
}

Washington. The chairman of the Senate subcommittee responsible for approving a large proportion of the annual US science budget suggested last week that, as industry is the main "customer" for much university-based research, industrial representatives should play a greater role in deciding how federal research funds are distributed.

The suggestion came from Senator Jay Rockefeller (Democrat, West Virginia) who chairs the subcommittee on science, technology and space. He was speaking at a two-day meeting organized by the Office of Science and Technology Policy (OSTP), widely seen as part of the preparation for an anticipated presidential white paper on how the United States can maintain its world leadership in basic science

Rockefeller suggested that industry might increase its influence over the science budget through, for example, greater representation on groups such as the National Science Board, the body that oversees the National Science Foundation (NSF). He also warned that if the US Senate votes on 22 February in favour of an amendment to the Constitution requiring the United States to balance its budget - as the House of Representatives has already done - the move could mean the end for new science projects.

The OSTP meeting provided an opportunity for more than a hundred researchers from academic institutions and industry to come together with the heads of most of the federal science agencies to talk about the importance of unfettered, curiosity-driven research.

Unsurprisingly, the scientists' main message was that the scientific enterprise needs more money. But the members of Congress who attended the meeting brought a different message, namely that future funding for science will depend on its success in creating jobs. This, for example, was the main theme of an address by Senator Barbara A. Mikulski (Democrat, Maryland) whose subcommittee controls the budgets of a number of science-based agencies, including the National Aeronautics and Space Administration and the NSF.

\section{Clinton budget proposes science funding freeze}

Washington. Small increases in science funding for the 1995 fiscal year, which starts this October, were proposed by President Bill Clinton when he presented his second budget to Congress on Monday ( 7 February). But the increases will be sufficient only to keep up with the anticipated rate of inflation.

The National Science Foundation (NSF) fares well in the submission, and the National Institutes of Health (NIH) less so, while both the National Aeronautics and Space Administration (NASA) and the Department of Energy face substantial cuts in parts of their research programmes.

The biggest increases will go to research related to new civilian technology initiatives, such as the planned information superhighway'. As a result, funding for applied research will rise slightly more than that for basic research.

The president proposes a 3.7 per cent increase in the federal research and development budget in 1995 compared to 1994 (excluding new research facilities in each case) to just over $\$ 71$ billion (see table). But after deep cuts in funding for new facilities, the increase would be only 2.7 per cent, probably close to the rate of inflation.

The proposed increases come as part of the first budget in which the total amount of 'discretionary spending' - that which the federal government is not obliged to make under the law - has been frozen in dollar terms by congressional decree. John Gibbons, the president's science adviser, says the increases therefore show that Clinton is "willing to cut other programmes to pay for research and development".

But Congress has yet to make its mark on the budget. And as proposed cuts in such politically sensitive areas as public housing work their way through the House of Representatives and the Senate, the modest increase for science is likely to be driven substantially below the expected rate of inflation.

The budget proposes no shift in the balance between civil and military research, with the latter still consuming 53 per cent of the total. Officials say spending has moved more quickly than planned in favour of civil research during Clinton's first year, and that the administra- tion is still aiming for parity between the two by 1998. But liberals will be dismayed that Clinton plans to increase defence research at the same 4 per cent rate as health research.

Technology transfer programmes organized by the National Institute of Standards and Technology - part of the Commerce Department - get the sharpest boost of all, jumping from $\$ 490$ million this year to $\$ 874$ million in 1995 , and programmes in various agencies related to the information superhighway being promoted by Vice-President Al Gore will rise from $\$ 964$ million to $\$ 1,272$ million.

Co-operative Research and Development Agreements (CRADAs) between government laboratories and private industry are also singled out for expansion.

Colin Macilwain

\section{NSF still keeps favoured agency status}

Monday's budget proposals have confirmed the favoured status that the NSF enjoys under the Clinton administration. In particular, the NSF is the only federal agency whose entire workload is identified by science adviser Jack Gibbons as a "priority area".

The administration has requested a 6 per cent increase in NSF's overall funding, which will reach $\$ 3.2$ billion in the fiscal year beginning on 1 October, with the research component growing by more than 8 per cent to reach $\$ 2.35$ billion.

"It's a very good budget in a very tough budget year," says Neal Lane, the director of NSF, adding that the entire budget $>$

Proposed increases by agency

\begin{tabular}{|c|c|c|c|}
\hline $\begin{array}{l}\text { Research and } \\
\text { development (R\&D): } \\
\text { (Budget authority : } \\
\text { \$ millions) }\end{array}$ & $\begin{array}{c}1994 \\
\text { enacted }\end{array}$ & $\begin{array}{c}1995 \\
\text { proposed }\end{array}$ & $\begin{array}{r}\text { Chang } \\
1994 t \\
1995\end{array}$ \\
\hline Defense & 35,538 & 36,971 & $4 \%$ \\
\hline $\begin{array}{l}\text { Health and Human } \\
\text { Services }\end{array}$ & 11,033 & 11,484 & $4 \%$ \\
\hline (NIH) & $(10,486)$ & $(10,994)$ & (5\%) \\
\hline Commerce & 919 & 1,204 & $31 \%$ \\
\hline NSF & 2,026 & 2,220 & $10 \%$ \\
\hline NASA & 8,493 & 8,597 & $1 \%$ \\
\hline Transportation & 617 & 692 & $12 \%$ \\
\hline EPA & 536 & 582 & $9 \%$ \\
\hline Agriculture & 1,393 & 1,394 & $0 \%$ \\
\hline Energy & 6,054 & 6,052 & $-0 \%$ \\
\hline Other & 1,876 & 1,833 & $-2 \%$ \\
\hline Total R\&D & 68,484 & 71,029 & $4 \%$ \\
\hline
\end{tabular}

( Figures exclude fundings for research facilities) 
submission was consistent with a recent request from a congressional committee that the agency should place more emphasis on so-called 'strategic' research.

No absolute cut is proposed for the funding of any scientific discipline. But some 'pure' disciplines are promised only moderate expansion - astronomy, for example, would receive a 5 per cent spending increase - while those closer to policy goals, such as social science and some branches of computer science, would get increases of 20 per cent or more.

c. $\mathbf{M}$.

\section{NIH: better than last year}

The administration's budget request for the NIH for the fiscal year 1985 is nothing to shout about. But in the face of tight controls on federal spending overall, the situation could have been worse. President Clinton is requesting $\$ 517$ million more in the year beginning on 1 October for NIH than in the current year, a modest increase of 4.7 per cent that would bring its budget to $\$ 11.5$ billion.

Apart from a few targeted areas research on women's health, and in particular breast cancer, HIV/AIDS and tuberculosis, support for high-performance computing and the minority health initiative, which are will all have healthy increases - funding for other research at NIH's 22 institutes and centres will remain level in real terms, the extra money amounting to little more than a cost-of-living increase.

Strong emphasis has been placed on research that is focused on the prevention of disease. Interestingly, however, the administration has frozen almost the entire budget for the Centers for Disease Control and Prevention, based in Atlanta, Georgia, which is the leading public health agency in the United States.

In addition to the $\$ 11.5$ billion requested for NIH, the administration has recommended that it should receive an additional $\$ 400$ million for research into prevention as part of the president's request for fiscal year 1995 for health-care reform.

Considering that this is a stringent budget overall, the president's request for $\mathrm{NIH}$ is better this year than last, says Harold Varmus, the director of NIH. "As long as we [NIH] are keeping ahead of the biomedical research and development price index, we're doing pretty well."

\section{Diane Gershon}

\section{Energy: cuts for nuclear}

With a request of $\$ 18.5$ billion for the 1995 fiscal year, the Department of Energy (DoE)'s budget is proposed by the Clinton administration to fall 3 per cent for the second year in a row.

The largest cuts proposed by the administration are in defence-related programmes (down 13 per cent, to $\$ 5.6$ billion) and nuclear energy research (down 25 per cent, to $\$ 248$ million). DoE plans to use some of these savings to increase spending on renewable energy and energy efficiency programmes, which would jump from a combined $\$ 1$ billion this year to $\$ 1.4$ billion in 1995 .

The $\$ 6.3$-billion request for environmental cleanup at former defence laboratories is roughly the same as this year's spending level, and remains the largest single item of expenditure in the department's budget.

The Office of Energy Research is requesting $\$ 2.8$ billion, down 15 per cent from the amount finally allocated to it in 1994 (largely as a result of the phasingout of the Superconducting Super

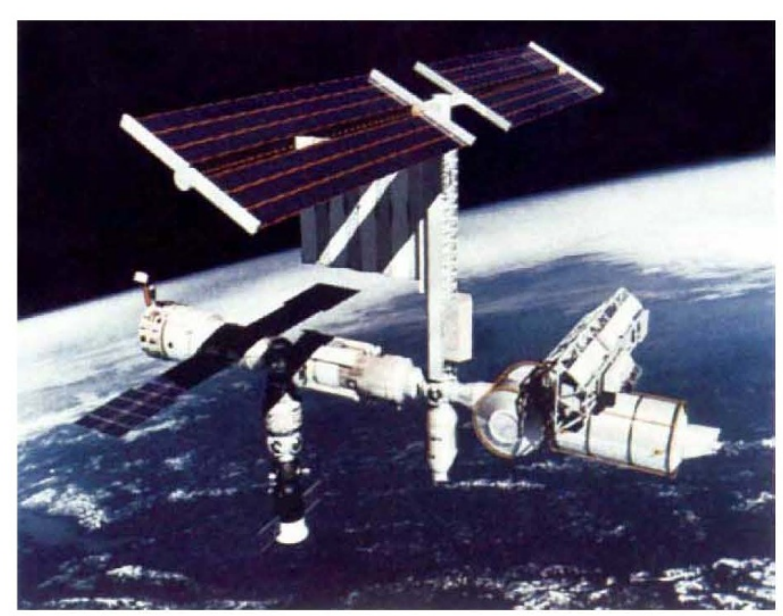

Space station funding remains at this year's level

Collider). More than a quarter of that amount goes towards DoE's programme of wide-ranging research in basic energy sciences, which is asking for slightly less than it received this year.

The 1995 request includes money to begin construction of the Tokamak Physics Experiment facility for fusion research at Princeton University, as well as the Advanced Neutron Source at Oak Ridge National Laboratory in Tennessee. It also continues funding for a variety of physics projects, such as the Advanced Photon Source, the B-Factory at Stanford University and the Relativistic Heavy Ion Collider. Funding for DOE laboratories will remain about level, although some will absorb significant cuts.

In the area of nuclear energy, the department plans to terminate research on two types of reactors deemed to have no near-term commercial return - the Advanced Liquid Metal Reactor and Modular High-Temperature Gas-Cooled Reactor. The Actinide Recycle Program also will be terminated. But research and development work on light water reactors will continue.

Tony Reichhardt

\section{EPA: bigger budget and more jobs}

After taking criticism from environmentalists for cutting last year's budget for the Environmental Protection Agency (EPA), the Clinton administration is proposing to reverse this with an 8 per cent increase to $\$ 7.2$ billion - the largest request in the agency's history.

Funding for the EPA's Office of Research and Development would rise 7 per cent to $\$ 570$ million, with an increased emphasis on ecosystems research. The agency also plans to convert 900 contractor positions to government employee status in 1995; in a move to boost its in-house scientific and technical expertise in-house.

T. $\mathbf{R}$.

\section{NASA: science up}

NASA will see its first real budget reduction since the early 1970 s, with a request of $\$ 14.3$ billion. This is $\$ 965$ million less than last year's budget request, and $\$ 251$ million less than the final 1994 figure approved by Congress.

Proposed spending on the international space station remains at this year's level of $\$ 2.1$ billion, while space science rises very slightly ( 2.5 per cent) to $\$ 1.77$ billion. Funding for both aeronautics and human space flight would be reduced from their 1994 levels.

Wesley Huntress, NASA's head of space science, says that this is "a good budget for us," with "no problems and no issues". Two large projects - the Cassini mission to Saturn and the Advanced XRay Astrophysics Facility (AXAF) remain fully funded, as do two low-cost planetary projects, namely the MESUR Pathfinder Mars lander and the Near Earth Asteroid Rendezvous (NEAR) mission. In addition, NASA is asking for money for a continuing 'Mars Surveyor' programme, which would send spacecraft to Mars once every two years.

NASA's funding request for the Earth Observing System and its related data network jumps by 46 per cent to $\$ 740$ million as the project gets closer to its first launch in 1998, while funding for life sciences and microgravity research are reduced. The agency's Advanced Concepts and Technology office gets a healthy increase, from $\$ 495$ million to $\$ 608$ million. Of that amount, $\$ 48$ million is requested for advanced small satellite technology - four times this year's amount. 